This is the accepted version of an article that will be published by Taylor and Francis in Journal of Development Studies:

http://www.tandfonline.com/loi/fjds20\#.VyiW6qMrLow

Accepted Version downloaded from SOAS Research Online:

http://eprints.soas.ac.uk/22392/

Christopher Cramer, Deborah Johnston, Carlos Oya, John Sender, SOAS University of London

\title{
Fairtrade and Labour Markets in Ethiopia and Uganda
}

\begin{abstract}
Drawing on four years of fieldwork in Ethiopia and Uganda, this paper addresses gaps in knowledge about the mechanisms linking agricultural exports with poverty reduction, the functioning of rural labour markets, and the relevance to the lives of the poorest people of Fairtrade. Statistical analysis of survey evidence, complemented by qualitative research, highlights the relatively poor payment and non-pay working conditions of those employed in research sites dominated by Fairtrade producer organizations. We conclude that Fairtrade is not an effective way to improve the welfare of the poorest rural people.
\end{abstract}

\section{Introduction}

Fair Trade certifying organizations claim to help inform those consumers who want to 'reduce poverty through their everyday shopping'. ${ }^{1}$ Information is, indeed, at the heart of a dilemma faced by many consumers: how to exercise consumption choices in conditions of great uncertainty (a proliferation of 
certification and standards schemes and labels) and very little information about the determinants of poverty. Fair Trade organizations deploy advocacy and branding campaigns to create rhetorical imagery and narratives that overcome the anxieties created by this uncertainty and lack of information.

As others have noted (Chiputwa, Spielman and Qaim, 2015), knowledge about the effects of private voluntary standards and 'ethical trade' certification labels is still limited and uneven. Furthermore, too little is known about the mechanisms linking international trade in agricultural commodities with poverty and poverty reduction (Winters 2002; McCulloch et al. 2001). And the state of knowledge on labour markets in low-income countries, especially rural labour markets, remains underdeveloped (Sender et al. 2005; Fields, 2007; World Development Report, 2008; Oya and Pontara 2015).

This paper reports research carried out at the intersection of these knowledge gaps. Specifically, and following the identification by others of a particular gap (International Trade Centre 2011; Terstappen et al. 2012), this paper reports on research on the labour market implications of Fairtrade, vis-à-vis other institutional production arrangements, in Ethiopia and Uganda.

Despite the lack of reliable evidence and the mixed results reported by available studies, it is claimed that: 'Fair trade seeks to change the lives of the poorest of the poor' (Fair Trade Federation, USA); and that 'Fair trade addresses the injustices of conventional trade, which traditionally discriminates against the poorest, weakest producers' (Fair Trade Foundation, www.fairtrade.org.uk/what_is_fairtrade/faqs.aspx). Expensive marketing materials featuring the beaming faces of certified farmers are combined with audit processes of questionable effectiveness, and with a few impact studies commissioned by Fairtrade International, the UK Fairtrade Foundation, and others, characterised by very uneven quality and weak description of data collection methods and analysis (Terstappen et al. 2012, Ruben 2013). A growing body of evidence based on more careful research methods reveals the limitations of these poverty reduction claims. 
This includes econometric analysis, which has usually focussed on producers (Ruben \& Hobinck 2015; Ruben and Fort 2012; COSA 2013) and, much less frequently, also wage workers (Valkila and Nygren, 2009; Dragusanu \& Nunn 2013). This paper's contribution is to add to the especially thin literature on the labour market implications of Fair Trade. The findings, presented below, challenge the claim that Fair Trade makes a positive difference to the welfare of the poorest rural people. ${ }^{2}$

\section{Fairtrade standards, 'theory of change' and wage employment}

Fairtrade has had two sets of standards for producer organizations seeking its certification: one set applied in Hired Labour contexts, understood to mean plantations or factories where most work is carried out by hired labour; and the other applied to Smallholder Producer Organizations (SPOs), where small-scale producers are considered to be farmers who are not dependent on permanent hired labour and who manage their enterprise mainly with a family workforce (http://www.fairtrade.net/small-producer-standards.html). Standards applied in Hired Labour contexts presume the creation of a 'joint body' representing both management and wage workers, which decides on the allocation of a 'social premium fund' in a democratic manner. Standards for SPOs historically paid no attention to wage employment and the representation of wage workers. This is because the SPO standards are based on the assumption that hired-in wage labour is negligible. The assumption remains despite promises to revise standards for SPOs in view of mounting evidence about the importance of hired labour among small-scale producers. ${ }^{3}$ Instead, the Fairtrade premium received by smallholders is intended to generate benefits to 'the community' through a democratic producer organization representing farmers rather than wage workers, i.e. in most cases a cooperative.

Fairtrade standards have changed over time and its hodgepodge of claims has been consolidated into a 'theory of change', which assumes that Fairtrade contributes to development by improving the rights of producers and workers. 
Fairtrade transactions exist, the theory goes on, within an implicit 'social contract' in which buyers (including final consumers) agree to do more than is expected by the conventional market, such as paying fair prices and subsidizing capacity building. In return, producers use the benefits derived from participating in Fairtrade to improve their social and economic conditions, especially among the most disadvantaged members of their organisation (emphasis added).

While Cramer et al (2015) presented evidence on the uneven distribution of gains among the members of SPOs, specifically three Fairtrade certified cooperatives, this paper addresses the implications of Fairtrade for wage workers. Wage workers, some of whom are also farmers, may reasonably be described, in terms of the Fairtrade theory of change, as 'the most disadvantaged members of their organisation' and our results illustrate their relative poverty. They are so 'marginalised' that they are bordering on invisible in many surveys and even in Fairtrade's own standards and audits. Remarkably little of the research on Fairtrade has investigated its implications for labour markets and wage employment (3ie, 2010; International Trade Centre, 2011; Trauger 2014). Recent exceptions include Valkila and Nygren (2009) and Dragusanu and Nunn (2014), who do not find clear evidence that Fairtrade benefits workers.

\section{Methods}

Some of the literature on Fairtrade emphasises the methodological problems in published impact assessments, especially the paucity of reported details on data collection and analysis (Cramer et al, 2014b; Terstappen et al. 2012, Trauger 2014; Ruben 2013). We stress these problems and, as described below, attempt to address some of these shortcomings. Experimental methods are not possible in this context (Chiputwa et al 2014). If there is quantitative evidence of better or worse performance by certified producers compared to non-certified ones, these results may be driven by ex-ante differences between the two groups, which are correlated both with certification and performance (Dammert and Mohan, 2014). 
Finding an appropriate 'control group' is difficult for many reasons, especially where an entire geographical area is affected by the certification and there are no uncertified producers in precisely the same area. The alternative of selecting adjacent areas not directly affected by the certification would be one possible, but far from ideal, way to address the common recommendation to find a 'counterfactual scenario'. In the context of certifications affecting entire areas a conventional 'control group' is simply not possible. Therefore, carefully selected comparable sites in other areas without certification can provide a possible proxy for a 'control group' so that selection bias is addressed. In addition ex-post techniques such as Propensity Score Matching can help reduce the potential bias although these can only be matched on observable characteristics for which there is data (Rijsbergen et al 2016). ${ }^{4}$

In fact, sites producing tea or coffee or flowers in rural Ethiopia and Uganda, even if apparently similar (characterised by 'smallholder' production of a particular crop, in the same region or district, etc.), and even if contiguous, are typically marked by a range of locally specific agronomic and microclimatic features, as well as many other characteristics that are often misleadingly described as 'unobservables', including infrastructural provision and the availability of alternative employment opportunities. While information can be collected on some of these aspects in each area, it is not always possible to account for all of the specific socio-political characteristics of every location. These differences are so important that they confound any prospect of purely similar research sites that could be isolated for 'treatment effect' of a single intervention. This does impose limits on the confidence in counterfactual causal mechanisms and explanations for observed phenomena, given that there are multiple determinants of outcomes. ${ }^{5}$

Much of the impact evaluation literature now recommends that quantitative evidence built on counterfactual analysis should be combined with qualitative assessments that provide additional information on processes and implementation contexts, in the context of theory-based, mixed-methods approaches to interventions in international development (Snilstveit, 2012). 
With these cautions in mind, we prioritised contrastive comparisons, identifying three main contrasting research sites for each commodity in each country and then selecting sub-sites within each of these. For example, for coffee in Ethiopia, in the first stage sites were selected because industry experts were unanimous that these sites produced extremely high quality coffee. Additional attributes were considered at the second stage: one site was selected because it had a very well-established Fairtrade certified producer organization (FPO) at its heart; ${ }^{6}$ another because it was defined as a comparable smallholder producer area but was not arranged around a Fairtrade certified producer organization; this site is the closest to a notional 'control group', because it allowed contrasts between two similar areas - both dominated by smallholder methods of production. The third site was selected because, although it contained many smallholders, it also contained several larger capitalist (non-Fairtrade certified) producers, many farming more than 100 ha of coffee, permitting additional comparisons in terms of scale of employer.

The objective of these contrasts was to assess the relative significance of wage employment in these sites and to investigate the differences, if any, in pay and working conditions, across sites (and between categories of workers). The research also sought to collect evidence on differences in welfare among respondents within each site sample, especially by comparing those who had and those who did not have recent experience working for wages in coffee, tea, and flower production. In all cases, the samples of wage workers employed by agricultural producers in areas with or without FT certification were randomly selected following a stratified sampling approach, designed to include different types of workers and particularly those who were the focus of this study - casual and seasonal workers.

Across the twelve main research sites, between 2010 and 2013, researchers devoted more than 1,000 person days to rural fieldwork (Cramer et al, 2014b). Once a sub-site was defined, the GPS coordinates of every residential unit in the site were recorded. Then, using handheld PDA computers with GPS sensors 
attached, enumerators carried out a quasi-census within the sub-site, asking a few simple questions to a total of 4,743 respondents, in order to construct a suitable sampling frame. ${ }^{7}$ We identified 'residential units' rather than households, and 'respondents' rather than 'household heads' to avoid the pitfalls of more common, but misleading, categories used in many household surveys (Cramer et al 2014b). This decision is particularly important in contexts where the target group - wage workers employed on a temporary basis and sometimes as seasonal migrants - may be excluded from official lists compiled by local authorities and from the more standard sampling frames, because they are living in temporary shelters, or in shared rented rooms that fail to conform to the living arrangements assumed by international definitions of 'households'.

The PDA data were then used to generate random, stratified samples of individuals from each of the sub-site populations. Enumerators used these samples to contact 1,700 respondents and complete detailed questionnaires. In all cases interviews were conducted outside the workplace, to avoid biases that might be caused by the presence of supervisors or employers. One or two years later, 401 respondents completed the same questionnaire. The aim of this repeat survey was to examine changes in the wage and non-wage benefits received by workers producing coffee in the light of a dramatic shift in international coffee prices.

The questionnaires made no attempt to gather detailed information about total 'household' income, which is notoriously difficult to obtain with any confidence (Anand and Segal, 2014). Such an attempt would have diluted innovative efforts to collect accurate and reliable data on wages and working conditions, the main focus of this research. In any case, most wage workers in the sample relied substantially on their agricultural wages and much less so on their tiny farm plots or any other sources of income (Cramer et al 2014a). The project's efforts focused on obtaining a detailed picture of labour market participation, education and demographic variables, but also constructed a proxy measure of socioeconomic status (using respondents' access to basic consumer goods). The findings of this research should therefore be assessed in relation to claims based 
on working conditions and an index score that is a robust proxy for standards of living, rather than on 'household income per capita'. The findings enable a comparison of conditions for those depending on access to wage employment, across sites and across institutional arrangements for production.

Finally, senior researchers returned to research sites to collect oral history interview material from 100 of the original main survey respondents and to organise focus groups on sexual harassment at work. These interviews provided insights that could not be captured in the standardised questionnaires. In addition, researchers interviewed dozens of other individuals who provided information on local contexts, as well as on how certification actually works, including, for example, on decisions about how to allocate the 'social premium' and on who benefits from these decisions. ${ }^{8}$

\section{Results}

This section reports on working conditions in FT and non-certified production areas, particularly in terms of wages but also providing evidence on a range of work benefits and non-wage conditions. The data showed that agricultural wage employment is widespread in those areas characterised by smallholder production. ${ }^{9}$ Moreover, people working for wages as casual and seasonal labourers in these contexts are likely to be among the poorest. This is seldom acknowledged by FT organisations, whose claims tend to focus on impacts on smallholder producers/employers.

Table 1 about here

This paper focuses on the striking differences in pay and conditions across research sites. Of particular interest is the difference between the experience of workers in sites defined around Fairtrade certified producer organizations (FPOs) and in other sites. The findings from simple descriptive wage comparisons (Figure 1 and Table 1) show that in Ethiopia, both flower and coffee wage workers in FPO areas were paid much less than those working in other 
non-FPO areas. Table 1 shows that in FPO areas nominal daily wages were less than 70 per cent of wages paid in areas without FT certification for both commodities in Ethiopia. In Uganda, in tea production the same pattern broadly holds, while in the coffee research sites workers in the FPO sites were on average paid no more than those in other sites. ${ }^{10}$ Except for coffee in Uganda, all differences in this table, by gender and certification status, are statistically significant.

Figure 1 about here

The results are striking because the comparisons control for the commodity and type of labour, since only manual agricultural labour is considered: the results do not emerge from a mix of different jobs on different crops. Variations in average rates are substantial, reflecting: the variety of forms of payment; the specific rate applied during a particular season; employer and worker characteristics; and the productivity of individual workers, among other factors. Despite these variations, FPO areas were clearly characterised by lower wages in most cases, whether comparisons were with large or small-scale non-certified farms. Given the large differences observed between the average wages for workers employed in FPO areas and those working in areas without certification we can be confident that this result is not random.

Simple differences between average wages and one-way ANOVA analysis are, however, not enough to confirm that the presence of certification is associated with lower wages. We used regression analysis to capture different correlates that might, in combination, explain some of this variation. The variables test the possibility that other intervening factors determine the variation observed, at the level of individual workers, employers or locations. Tables 2 and 3 report the results for coffee production in Ethiopia and Uganda, as an illustration. ${ }^{11}$ Sociodemographic characteristics of workers, their education, seniority and experience in the same job, are combined with a number of employer characteristics, such as scale and non-wage benefits (as proxies of better conditions in other dimensions and greater 'formality'), and location-specific 
dummies. Payment methods, most frequently taking the form of a daily wage or task/piece-rates, were remarkably similar between areas with and without FT certification, and are therefore unlikely to underpin such differences. For each case various specifications are tested, with different sets of factors included and alternative standard error estimation methods. The regression analysis is not designed to make causal claims about individual variables, including FT certification. The point is to see to what extent the correlation with FT certification changes when controlling for some other important factors, and particularly once we take into account the possible sources of selection bias (such as large scale vs. smallholder employers) that could underpin the descriptive results. The analysis, combined with the qualitative evidence presented below, provides a more complete picture of the variation in conditions and suggests that there is no evidence of Fairtrade certification having any positive association with the outcome variables. ${ }^{12}$

Tables $2 \& 3$ about here

In all cases, results confirm that there are lower wages in FPO areas even after controlling for a range of potentially influential factors. Even where basic descriptive differences are not conclusive (Uganda coffee) the regression results reveal a statistically significant and strong negative correlation between FT certification and the level of nominal wages, other things being equal. In other words, when jobs on small-scale farms that are not in an FPO area are compared to jobs on small-scale farms located in FPO areas, the wage levels are clearly lower in the latter.

In the four sets of regressions (for coffee in Ethiopia and Uganda, flowers in Ethiopia and tea in Uganda) the variables that are most significantly and consistently correlated with wage levels were: sex, i.e. male $(+)$, completion of primary school $(+)$, household size $(+)$, scale of employer/producer $(+$, only in Ethiopia, and partly in Ugandan tea - see more below), time in same job (-), and Fairtrade certification (-). The average gaps between wages in FPO and non-FPO areas of production are confirmed and even strengthened by regressions, i.e. 
after various factors have been controlled for. These results are intuitively convincing, suggesting well-known patterns of gender discrimination (women receiving on average lower wages other things being equal) and positive returns to the most basic education (a few years of primary schooling), particularly relevant to the very poor manual agricultural workers in these samples. Other variables generally correlated with rural socio-economic status (household size and a basic asset index - called 'simple poverty index') also had a positive association with wage levels. In short, more educated men from slightly more wealthy and larger households tend to command higher daily wage rates than other workers.

Agricultural wage variation is a complex phenomenon, and an adequate analysis is beyond the reach of regression analysis. It is possible that the variation in the estimated daily wage rate - the dependent variable - is in part the outcome of different individual productivity levels when workers are paid by piece rate (see more below). However, we did not run regressions on each sub-category of payment (time, task, piece-rates, and so on) since there were too few observations for consistent estimates.

The evidence on the degree to which farm size influences wage levels is mixed, although in most of our samples there is a tendency for larger-scale farmers to pay higher wages than other employers. This is especially true in the case of coffee in Ethiopia, where large-scale coffee producers (primarily concentrated in the Jimma area) paid significantly higher wages than small-scale producers (certified or not) in the Sidamo area. In flowers, we did not control for scale in regressions, as there was no clear distinction in terms of size. However, the highest wages were clearly found in Ziway, where workers for the largest flower corporation in Ethiopia were sampled. Indeed, one lesson from qualitative research on flower production sites was that scale might not be the critical factor determining wages. Here, given a certain scale, substantial variation in working conditions was found on different flower farms all of whom had distinct characteristics in terms of management practices, capital origin, technological choices, size of investment and so forth. 
In Ugandan coffee, the data show no significant size effect, although small-scale farmers seemed to pay higher wages on average. This may be because the most important large-scale employer in the sample, Kaweri coffee plantation, offered a 'standard' daily wage to large numbers of people working for longer periods, whereas most small-scale producers employed casual labour paid by task mainly recruiting during peak periods where competition for labour was most intense. Many of the workers in Kaweri were also migrants residing in workers' compounds constructed by the plantation management; they received additional benefits from their employer. However, it is also striking that a subset of smallscale farmers based in Masaka and without Fairtrade certification paid much higher wages than the majority of small-scale producers located in the areas with certification. This result then partly explains why size is not statistically significant while Fairtrade certification is.

For tea in Uganda, where 'small-scale' producers employed significant numbers of workers, wages are on average higher on larger farms but not significantly so. This may be because of the difficulty in establishing clear categorical boundaries between 'small' and 'large' scale in the tea producer sample (Cramer et al, 2014a). ${ }^{13}$ More disaggregated evidence, however, shows that the largest-scale farm in Uganda managed by a major tea multinational (Mcleod Russel) paid daily wages that were almost double the average and certainly much higher than most other large-scale producers. This huge variation within our 'large-scale' tea category explains why the scale variable is not statistically significant in Uganda.

To reiterate, in the regression results, even controlling for size, workers were on average paid less in FPO sites. They were paid more, on average, in 'other' sites whether these are characterised by the presence of large producers or by a prevalence of 'smallholder' employers. These findings may have important implications for poverty reduction policies. For example, there is a policy dispute between Fairtrade USA and Fairtrade International, because the American organisation insists on trading with and certifying large-scale coffee plantations, 
arguing that wage workers will benefit if large-scale producers are also Fairtrade certified (Neuman, 2011).

In some research sites, relatively few workers receive very low wages. In the Ethiopian coffee sites for example, less than 5 per cent of coffee wage workers in 'non-certification' sites earned less than 60 per cent of the median wage. The equivalent figure for the site defined around a Fairtrade certified coffee cooperative was an extraordinary 30 per cent. A similar pattern was found in the flower producing sites in Ethiopia, and also in Uganda, where between 17 and 30 per cent of workers earned below 60 per cent of the median wage in Fairtrade production sites, while only 5 per cent of those working in both coffee and tea areas without Fairtrade certification earned so little. ${ }^{14}$

Were these lower wage rates in FPO sites compensated for by better non-pay labour market conditions and/or by the offer of more days of employment per year? As Figures 2 and 3 show, during the previous 12 months, large-scale coffee employers in Uganda and Ethiopia offered twice as many days of labour as did small-scale producers. Across all sites in Uganda, coffee employers in FPO areas offered 68 days, compared with 91 days for employers in sites without certified producer organizations. ${ }^{15}$ The implication is that, in all coffee sites, agricultural workers received significantly higher annual earnings on large-scale farms and in the non-FPO production sites.

Figures $2 \& 3$ about here

The remarkably clear and consistent pattern of differences between areas with FPOs and other research sites is reinforced by some of the data on non-pay employment conditions. Thus, for example, in Ethiopian coffee only 1 per cent of FPO site wage workers reported that they received any payments for medical care compared to 11 per cent of wage worker respondents in other sites and 56 per cent in large-scale state farms. Similarly, a higher share of coffee workers in non-FPO sites than in FPO sites reported that they were compensated for working overtime. These lower standards were only partly compensated for by a 
lower incidence of payment delays and a larger proportion of free meals on farms in FPOs. In the Ugandan coffee producing sites only 7 per cent of FPO workers were compensated for working overtime, but 94 per cent in the other sites; and none of the Ugandan FPO workers surveyed reported any coverage of medical costs by their employers, while 19 per cent of those in other sites did get some coverage. In Ugandan tea, the differences were much narrower overall. However, a comparison between Fairtrade tea cooperatives and a plantation run by a well-known non-FT certified tea multinational showed much better standards in the latter across a range of criteria, including provision of housing and shower/toilet facilities, free meals, paid leave, and especially on childcare provision and payment delays (see Cramer et al 2014a, p. 88 Table 3.13), The differences were also consistent (and worrying for advocates of Fairtrade) in Ethiopian flower production. Therefore, overall, and despite a few exceptions, non-wage standards were better in non-FPOs.

Scale matters. A comparison between certified and uncertified small scale coffee farms shows that generally small-scale employers fail to provide better conditions to their workers. When sites with small-scale producers are compared, differences are marginal, not always in favour of small-scale employers in FPO sites, and, overall, the FPO record shown in Tables 3.10 and 3.11 of Cramer et al (2014a) is rather unimpressive. In coffee production in Ethiopia, the best non-wage conditions are found in the large-scale non-certified state farm, far better than in the FPO smallholder production areas. Fairtrade cooperative processing stations are also less likely to provide housing, free meals and paid medical care, while the local private uncertified coffee processors perform slightly better. In the case of tea production in Uganda, the best working conditions by far are offered by the large-scale estate owned by a multinational corporation without FT certification. ${ }^{16}$

Qualitative research led to the conclusion that the much-lauded 'social projects' paid for (at least in part) with funds from the Fairtrade premium did not benefit all in the 'community' equally. We found that many of the poorest do not have access to these facilities. In one Fairtrade tea cooperative, the premium has been 
used to fund improved toilets and a health clinic. The modern toilets were exclusively for the use of senior co-op managers. And the clinic is only free to permanent workers at the tea factory. Temporary workers plucking tea, who may work for several years on such contracts, and other local people must pay. We interviewed clinic staff, local residents, temporary and permanent workers and found that clinic fees put off all but the wealthiest local residents. One man, James, is desperately poor and lives with his elderly father in an inadequate shack close to the tea factory. Although his father was once a temporary worker at the tea factory, James is charged fees at the tea factory's Fairtrade health clinic. He cannot afford them and instead, although he only has one leg, he hobbles more than $5 \mathrm{~km}$ to receive free treatment at a government clinic. Meanwhile, managers of other - free access - health clinics in the area told of their resentment at the Mpanga clinic's ability to ration access.

In another case at a Ugandan coffee cooperative supported by Fairtrade, very poor children were turned away from the Fairtrade supported school as they owed fees. This was despite the fact their mothers were working for members of the cooperative. In this case, the Fairtrade premium went not to support access of the very poor but to build houses for the teachers, including for the headmaster. Workers confirmed that this school had expelled some of the poorest workers' children because they had not been able to pay the school fees or purchase books. We found similar stories about a lack of access to Fairtradesupported schools in Ethiopia. At the Fairtrade certified flower farm in Ethiopia at the heart of one of our research sites, a large sum of money had accumulated in the Fairtrade premium fund and could not be spent at all. ${ }^{17}$

\section{Discussion}

Overall the quantitative and qualitative evidence shows that Fairtrade certification did not have a discernible positive effect on the poorest local people. Why? Several insights from our research help answer this question: (a) poor monitoring of labour standards; (b) a weak transmission mechanism between coffee prices received by producers and the wages of their workers; (c) other 
causes of variation in product and labour markets; and (d) the overall inability of Fairtrade significantly to affect local labour market dynamics.

(a) Poor monitoring of labour standards

Fairtrade certification has overlooked the existence of wage workers. In certified SPOs Fairtrade failed to rigorously monitor the wages and working conditions of casual and seasonal wage workers, even those seasonal wage workers directly employed by Cooperative Unions. Very poor treatment of wage workers seems quite compatible with continued certification.

This is true even in HLOs, where Fairtrade has proven institutionally incapable of effectively monitoring the wages and conditions of those working on large farms (e.g. flowers), despite the existence of auditing procedures included in the Hired Labour Standard. For example, on the only Fairtrade certified estate in Ethiopia producing cut flowers while this research was being carried out, workers' basic rights were routinely flouted and management was able to evade attempts by Fairtrade certifiers to promote the interests of employees. Fairtrade auditors need to make a radical break with easily evaded box-ticking techniques and to spend much more time in the field interviewing workers who have not been selected by the management. The ease with which employers can evade the standards and monitoring efforts of certifiers has also been shown elsewhere, for example by research in China (Chan, 2010; Taylor, 2011).

Interviews in Ishaka (ACPCU) suggested that the auditing process took very few days mostly spent in Ishaka headquarters going through the paperwork prepared by the ACPCU secretariat. Only one or two days were devoted to tours of a few pre-selected smallholder farmers, the rationale and method for whose selection was untransparent. Interviews with the largest 'smallholder' producers of certified tea in Uganda made it clear that none of their wage workers had ever been contacted by a visiting auditor. 
(b) The weak transmission mechanism between coffee prices received by producers and the wages of their workers

It is not even clear that Fairtrade certification of producer organizations significantly raises revenues for most member-farmers (Minten et al, 2015; Mituku et al 2015); this limits any potential 'trickle-down' to workers earnings. First, for some of the crops under consideration, such as coffee in Ethiopia, the Fairtrade minimum price has for some time been far below the local market price (Mezlekia, 2012). Second, even when the price is higher, it is common for Fairtrade cooperatives to sell only a very small share through the Fairtrade channel (Dragusanu and Nunn, 2014: 12). Third, the revenue from these sales is distributed highly unevenly (Cramer et al 2014c). Those few with larger farms and a greater volume of sales through the cooperative benefit more from the price and other advantages that may come with certification - access to NGO support, the benefits of direct trading permits, etc. - than the vast majority of smallholder members who can barely sell any output through the cooperative, let alone through Fairtrade channels. Finally, re-surveys of wage workers in 2013 after major shifts in the price their employers received for coffee showed no clear relationship between these price shifts and levels of real wages. There was no evidence of any trickle down to workers from the payment of Fairtrade prices to employers. Indeed, in the short-run (one to two years) differences in real wages between FPO sites and non-certified areas actually widened over time (Cramer et al 2014a: 90-97).

(c) Other causes of variation in product and labour markets

One possible explanation for variations between sites in returns to labour is that site characteristics differ. The argument would be that payments and conditions might be better in one smallholder site if, for example, that site has better soil, is closer to a good road and there are more local non-farm employment opportunities, resulting in higher average standards of living and moderately tighter labour markets. However, in the smallholder sites these differences could 
not account for all of the labour market variations observed. For example, wages were on average higher and conditions better in the Ethiopian non-FPO than in the FPO smallholder coffee site. But this non-FPO smallholder site was obviously more remote and poorer. Nevertheless, at the centre of the remote non-FPO site there was a particularly large coffee washing station - said to be the largest in Africa - that had developed a close long-term relationship with a company with a branded international reputation for high quality coffee. This Italian company had made efforts to ensure continuity of high quality supply; it therefore encouraged good cultivation and harvest practices by paying higher than average prices to the washing station for final output. This relationship, sustained over nearly two decades, may explain the higher average wages and superior working conditions found in this site.

Some other evidence also suggests a relationship between higher quality coffee cultivation practices and daily wages: in the FPO sites, coffee harvesting piece rates were generally lower (by about 20 per cent) than the rates offered to coffee harvesters in other sites. Coffee harvesters in FPO sites earned lower daily wages than elsewhere not only because their piece rates were lower but, more importantly, because the total weight of coffee each worker managed to harvest in a day was smaller. It is unlikely that large numbers of the most skilled, efficient and productive harvesters happened to be concentrated in the non-FPO sites; it is more likely that, on average, each tree in the non-FPO sites contained a high proportion of large ripe coffee cherries when the harvesters were hired, allowing workers rapidly to complete their minimum daily task and then to a earn a relatively high daily income. ${ }^{18}$

There appears to be considerable room for discretion among employers in how they treat workers. There may be some non-formal 'norms' influencing expectations in each research site, but they do not prevent variation within sites. The particularities of specific management practices, which do not affect all the workers in a sector, also play a key role. For example, in flower production, the only flower farm with Fairtrade certification when the study began was a relatively large producer, but had a very fraught history of labour relations. 
Morale among workers was low and there had been several labour disputes. In contrast, one smaller flower farm producing for a high value niche market had a strong reputation among local workers for higher pay and better working conditions. Finally, one very large foreign owned firm had built a hospital and school. The owner of this firm, when interviewed at the start of the project, rejected the idea of Fairtrade but after the end of data collection he did secure Fairtrade certification. Relatively decent working conditions on this farm and the owner's consistently high levels of expenditure on Corporate Social Responsibility pre-dated and had nothing to do directly with Fairtrade certification.

(d) What scope for intervention?

Two factors that allow for employer discretion in treatment of workers are, first, slack in the rural labour market-a large over-supply of poorly educated workers relative to labour demand, but wages could barely be any lower so in these rural areas a 'market clearing wage' is inconceivable; and, second, an 'enforcement gap', i.e. the difficulty policy makers have in reaching into a world of scattered employers in economies with limited infrastructure and often difficult terrain. In the prevailing socio-economic context in countries such as Ethiopia and Uganda it is extremely unlikely that direct labour market interventions (e.g. minimum wage and health and safety legislation) could easily be monitored and enforced.

It is more likely that labour market slack could be addressed indirectly through state support for investments that help tighten labour markets. A productive investment strategy, prioritising infrastructure and crop yield improvements, could be combined with efforts to tighten the labour market by enforcing compulsory education up to the age of at least 16 and so reducing the annual flow of new entrants into the agricultural labour market. For we found - both in the large survey and in qualitative interviews -widespread participation in paid labour by very young adults (those aged between 14 and 18 years) as well as by even younger children. ${ }^{19}$ Child labour was commonplace across all institutional 
settings and research sites, including the FPO sites. ${ }^{20}$ Large numbers of very young people are being pitched into wage labour, and our qualitative evidence suggested that in the process they often have to drop out of school. Not only does this weaken their own future labour market prospects; it also exerts downward pressure on wages by swelling labour supply.

\section{Conclusions}

Nelson and Pound (2009), commissioned by Fairtrade, acknowledged how little is known about the labour market implications of Fairtrade. Like those other contributions that do engage with the wage employment dimensions of Fair Trade (3ie 2010), but with more evidence than most, our research finds that Fair Trade is not effective in protecting the rights of or improving the welfare of poor rural wage workers, relative to other institutional settings for agricultural export production. This suggests that Fair Trade is neither an effective mechanism for poverty reduction among the poorest (especially wage workers) nor an efficient way to promote the emergence of a group of highly productive rural capitalists. The elite within FPOs receives favourable terms and privileged access to resources (Cramer et al, 2014c) but without any clear criteria designed to select the most productive, and without adequate capacity to monitor or enforce the 'social contract' promised to well-meaning Western consumers.

Our evidence suggests some alternative areas for research and policy attention, if the goals are both to stimulate competitive export oriented agriculture and to improve the lot of the poorest people in rural societies. The evidence does point - with important qualifications - to the tendency of larger scale producers to offer more days of work, to pay more per day, and to offer better non-pay conditions of employment. The larger producers are also more readily within 'policy reach' than the thousands of scattered smallholders. Clearly, though, not all larger farmers behave equally efficiently or treat their workers decently: scale does not act as an automatic vector of developmental change. The implications are that policy makers could design interventions that have a realistic chance of 
being implemented, that are more likely to contribute to rapid growth of

productivity and to efforts to address the binding balance of payments constraint on growth in low-income countries (Thirlwall, 2011), and that have a greater chance of generating poverty-reducing wage labour opportunities - if they are concentrated on the relatively large and best managed farms. That larger agricultural producers often fall short of their evident potential points to the need to combine any favourable policy support for them with the enforcement of discipline or what Amsden (2001: 8) termed a 'reciprocal control mechanism'.

This research project has shown the importance of the conditions of employment in agricultural commodity production for the welfare prospects of extremely poor people, particularly for poor women. It has also shown that private voluntary standards, using institutional innovations like Fairtrade, are likely to fail to make a difference to these people's welfare.

Tables and Figures

Table 1. Fairtrade certified (average) daily wages as a percentage of nonFairtrade certified (average) daily wages

\begin{tabular}{|l|c|c|c|c|}
\hline & $\begin{array}{l}\text { Female manual } \\
\text { agricultural } \\
\text { workers }\end{array}$ & $\begin{array}{l}\text { Male manual } \\
\text { agricultural } \\
\text { workers }\end{array}$ & $\begin{array}{l}\text { Total manual } \\
\text { agricultural } \\
\text { workers }\end{array}$ & $\begin{array}{l}\text { Total sub- } \\
\text { sample } \\
\text { (N) }\end{array}$ \\
\hline Coffee sites Ethiopia & $71 \%$ & $62 \%$ & $67 \%$ & 433 \\
\hline Coffee sites Uganda & $85 \%$ & $110 \%$ & $99 \%$ & 282 \\
\hline Flowers sites Ethiopia & $71 \%$ & $59 \%$ & $67 \%$ & 225 \\
\hline Tea sites Uganda & $71 \%$ & $67 \%$ & $74 \%$ & 206 \\
\hline
\end{tabular}

Notes: 1 . These calculations refer to the sub-sample of manual agricultural workers in each target commodity, i.e. we compare the average daily wages among manual coffee/flower/tea workers by certification status. The reported wages exclude respondents working for wages in other commodities. 2. Reported values are nominal daily wage rates. The methods of payment may have been in the form of piece-rates, task-rates, daily and monthly payments. Each modality was translated into daily equivalents. 3. All mean differences are statistically significant at $1 \%$ level except for differences in wage rates for the overall sample of coffee wage workers in Uganda.

Source: Cramer et al, 2014a. 
Figure 1. Average nominal daily wages (Birr), by product and certification status in Ethiopia

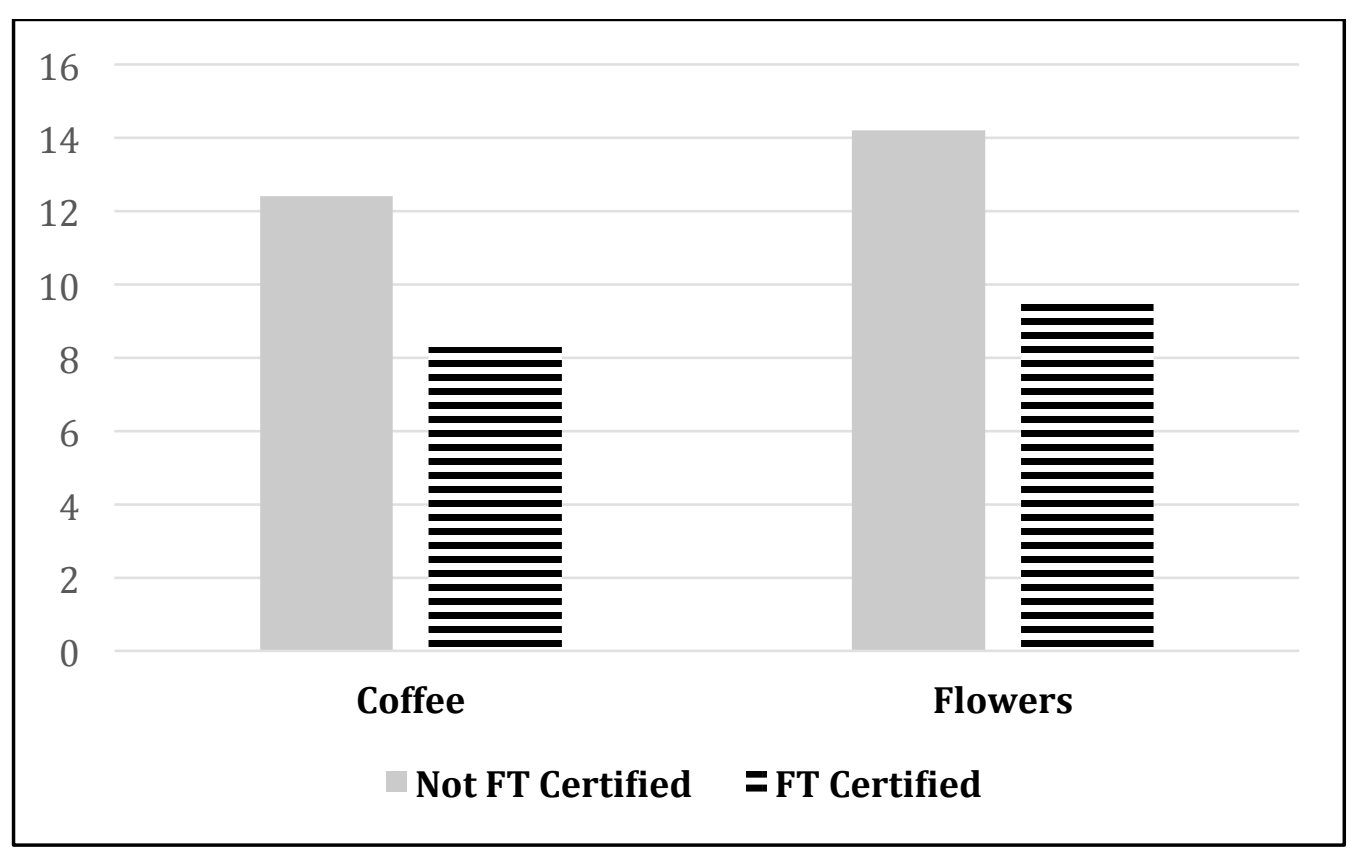

Source: Cramer et al, 2014a. 
Table 2 Regression analysis of average wages in coffee production in Ethiopia

\begin{tabular}{|c|c|c|c|c|c|c|}
\hline & \multicolumn{2}{|c|}{ M1 } & \multicolumn{2}{|c|}{ M2 } & \multicolumn{2}{|c|}{ M3 } \\
\hline & b & SE & b & SE & b & SE \\
\hline FT certification & $-2.396^{* * *}$ & $(0.62)$ & $-2.286^{* * *}$ & $(0.52)$ & $-1.989 * * *$ & $(0.57)$ \\
\hline Large-scale farm & 2.506 & (1.49) & $3.306^{* *}$ & $(1.02)$ & $3.391 * * *$ & $(1.00)$ \\
\hline Small-scale farm & -0.244 & $(0.75)$ & -0.061 & $(0.57)$ & -0.132 & $(0.64)$ \\
\hline State farm (large-scale) & 0.492 & $(1.19)$ & 1.080 & $(1.16)$ & 0.985 & $(1.10)$ \\
\hline Gender Dummy; 0: Female 1: Male & $1.946^{* *}$ & $(0.61)$ & $2.192 * * *$ & $(0.53)$ & $2.125^{* * *}$ & $(0.51)$ \\
\hline Age in years & -0.009 & $(0.03)$ & -0.015 & $(0.02)$ & -0.014 & $(0.02)$ \\
\hline Highest Schooling Dummy: Not Completed Primary Scho & -0.942 & $(0.69)$ & -0.168 & $(0.57)$ & -0.160 & $(0.56)$ \\
\hline Highest Schooling Dummy: Primary & 2.299 & $(1.32)$ & $2.975^{* *}$ & (1.14) & $2.886^{* *}$ & (1.07) \\
\hline Highest Schooling Dummy: Junior Secondary & -0.901 & $(1.24)$ & & & & \\
\hline Highest Schooling Dummy: High School & -1.762 & $(1.20)$ & -1.388 & $(0.95)$ & -1.312 & $(0.97)$ \\
\hline Current Education Status Dummy; 0: Not in School & -1.170 & $(0.97)$ & & & & \\
\hline Used Health Facilities in Last 12 Months? & -0.850 & $(0.51)$ & & & & \\
\hline Time in Job in Days & -0.000 & $(0.00)$ & $-0.001 *$ & $(0.00)$ & $-0.001 *$ & $(0.00)$ \\
\hline mber of all members) & 0.266 & $(0.14)$ & $0.341^{* *}$ & $(0.12)$ & $0.298^{* *}$ & $(0.10)$ \\
\hline Child Mortality Indicat & -0.022 & $(0.02)$ & & & & \\
\hline Simple Poverty Index & 0.182 & $(0.14)$ & $0.362 *$ & $(0.17)$ & $0.399 *$ & $(0.16)$ \\
\hline Free/subsidised meals? & 0.091 & $(0.63)$ & & & & \\
\hline Payment Delays During Last 3 Years? & 0.011 & $(0.73)$ & & & & \\
\hline Total number of days missed in last 12 months & -0.014 & $(0.02)$ & & & & \\
\hline loyer provide & 0.306 & $(0.98)$ & & & & \\
\hline Did the employer provide you with loans/wage advance & -0.620 & $(0.63)$ & & & & \\
\hline Location dummy - Wollo village (LSF) & & & & & -0.639 & $(1.53)$ \\
\hline Location dummy - Kossa village (State farm) & & & & & -0.600 & $(0.95)$ \\
\hline Location dummy - Ferro 1 (SS Fairtrade) & & & & & -0.868 & $(0.65)$ \\
\hline Location dummy - Sisola North (SS non FT) & & & & & 0.774 & $(1.31)$ \\
\hline Constant & $8.883^{* * *}$ & $(1.62)$ & $6.396^{* * *}$ & $(1.31)$ & $6.641 * * *$ & $(1.30)$ \\
\hline $\mathrm{r} 2$ & 0.225 & & 0.195 & & 0.198 & \\
\hline observations & 318 & & 422 & & 422 & \\
\hline
\end{tabular}

Note: 1/ Regressions run considering all manual agricultural jobs; standard error clustered at level of individual workers. Location dummies refer to sub-sites within each location category, thus not perfectly correlated with other variables such as certification or scale. 2/ OLS for all jobs sampled, with clustered standard errors

Source: Own analysis from project survey data 
Table 3. Regression analysis of average wages in coffee production in Uganda

\begin{tabular}{|c|c|c|c|c|c|c|}
\hline & \multicolumn{2}{|c|}{ M1 } & \multicolumn{2}{|c|}{ M2 } & \multicolumn{2}{|c|}{ M3 } \\
\hline & b & SE & b & SE & b & SE \\
\hline FT certification & $-964.54 *$ & $(421.52)$ & $-933.01 *$ & (373.07) & $-1043.58 *$ & (494.68) \\
\hline Small-scale farm & 183.26 & $(427.39)$ & 393.01 & $(403.13)$ & 378.45 & $(440.90)$ \\
\hline Gender Dummy; 0: Female 1: Male & 353.66* & (166.77) & 471.78** & (159.40) & 476.99** & (161.05) \\
\hline Age in years & 6.94 & (7.53) & $14.26^{*}$ & (6.78) & 12.82 & (6.81) \\
\hline $\begin{array}{l}\text { Highest Schooling Dummy: Not Completed } \\
\text { Primary }\end{array}$ & 121.62 & (310.14) & 62.82 & (227.41) & 93.16 & $(230.37)$ \\
\hline Highest Schooling Dummy: Primary & 35.94 & $(309.07)$ & 50.90 & $(235.79)$ & 102.73 & $(235.67)$ \\
\hline Highest Schooling Dummy: Junior Secondary & 10.93 & $(329.27)$ & & & & \\
\hline Current Educational Status - 0: Not in school & -174.80 & $(326.01)$ & & & & \\
\hline Used Health Facilities in Last 12 Months? & 293.46 & $(366.68)$ & & & & \\
\hline Time in Job in Days & $-0.127^{*}$ & $(0.06)$ & $-0.12 *$ & $(0.06)$ & $-0.11 *$ & $(0.06)$ \\
\hline Household size (number of all members) & 58.17 & $(31.04)$ & 39.44 & $(30.05)$ & 43.71 & $(31.35)$ \\
\hline Child Mortality Indicator & 5.13 & $(4.50)$ & & & & \\
\hline Simple Poverty Index 1 (higher = less poor) & 61.75 & $(36.04)$ & & & & \\
\hline Free/subsidised meals? & $-561.63^{*}$ & $(229.40)$ & -431.24 & $(245.32)$ & -354.26 & $(257.88)$ \\
\hline Payment Delays During Last 3 Years? & 100.68 & $(189.73)$ & & & & \\
\hline Total number of days missed in last 12 months & -1.74 & $(4.20)$ & & & & \\
\hline $\begin{array}{l}\text { Does the employer provide free or subsidised } \\
\text { housing? }\end{array}$ & 196.00 & $(320.92)$ & -4.17 & $(295.33)$ & -104.44 & $(304.20)$ \\
\hline $\begin{array}{l}\text { Did the employer provide you with loans/wag } \\
\text { advances? }\end{array}$ & 359.11 & $(268.26)$ & & & & \\
\hline Location dummy - Kijunga village (Kaweri) & & & & & $-367.02^{*}$ & $(162.23)$ \\
\hline $\begin{array}{l}\text { Location dummy - Kinvunikidde (SS non- } \\
\text { Fairtrade) }\end{array}$ & & & & & -65.38 & $(364.84)$ \\
\hline Location dummy - Kibutamo (SS Fairtrade) & & & & & 93.76 & $(288.20)$ \\
\hline Constant & $1624.96^{* * *}$ & $(479.96)$ & $2143.44^{* * *}$ & $(370.38)$ & $2187.09^{* * *}$ & (364.88) \\
\hline $\mathrm{r} 2$ & 0.180 & & 0.102 & & 0.111 & \\
\hline observations & 267 & & 289 & & 289 & \\
\hline
\end{tabular}

Note: 1/ Regressions run considering all manual agricultural jobs; standard error clustered at level of individual workers. Location dummies refer to sub-sites within each location category, thus not perfectly correlated with other variables such as certification or scale. 2/ OLS for all jobs sampled, with clustered standard errors

Source: Own analysis from project survey data 
Figure 2. Job duration for coffee wage workers, Ethiopia

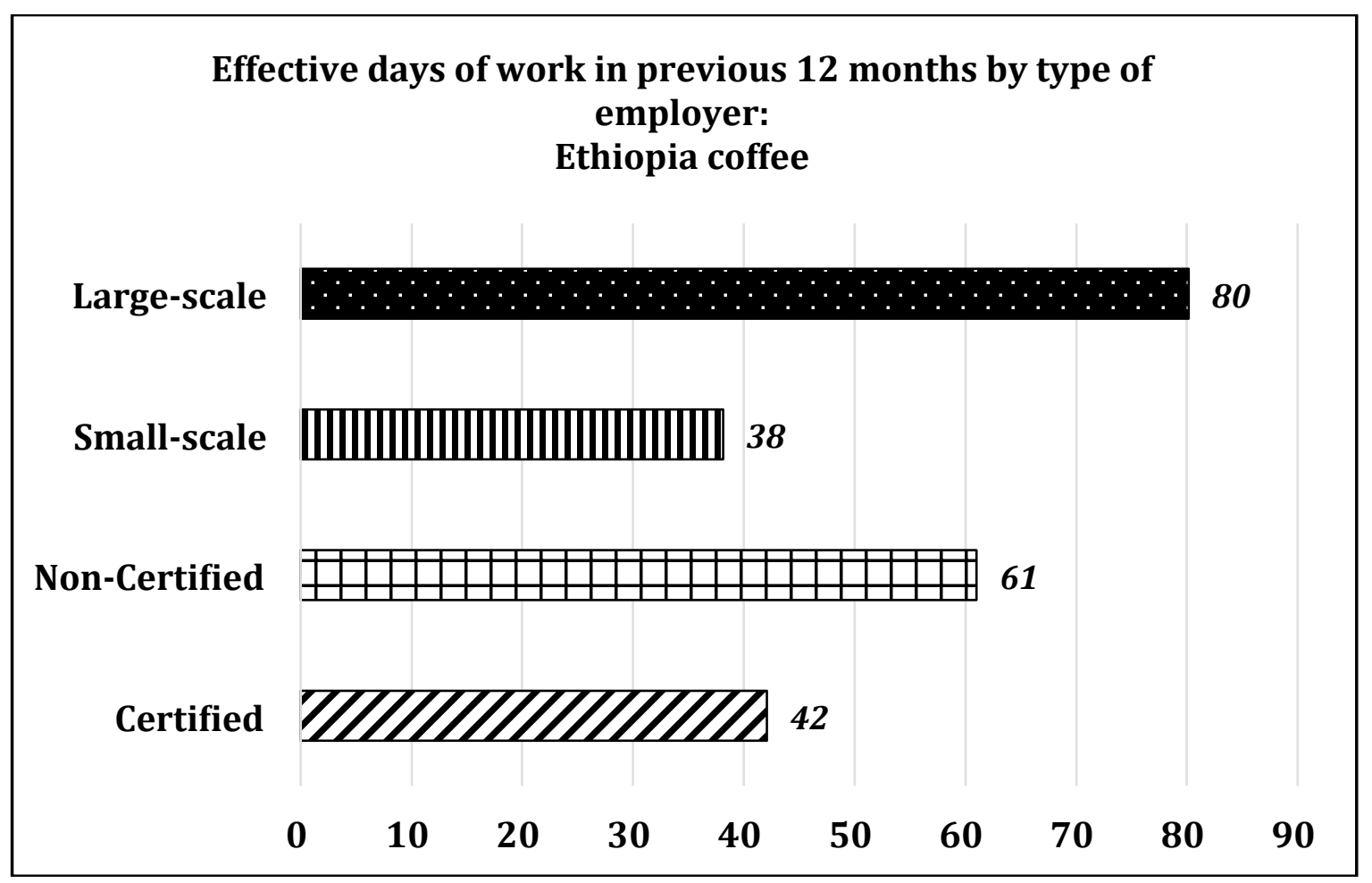

Notes: 1/ These figures are for comparable samples of manual coffee workers paid on a daily or monthly basis. 2/ The duration refers to individual jobs. 3/ 'certification' refers to Fairtrade certification. Source: Cramer et al, 2014a.

Figure 3. Job duration for coffee wage workers, Uganda

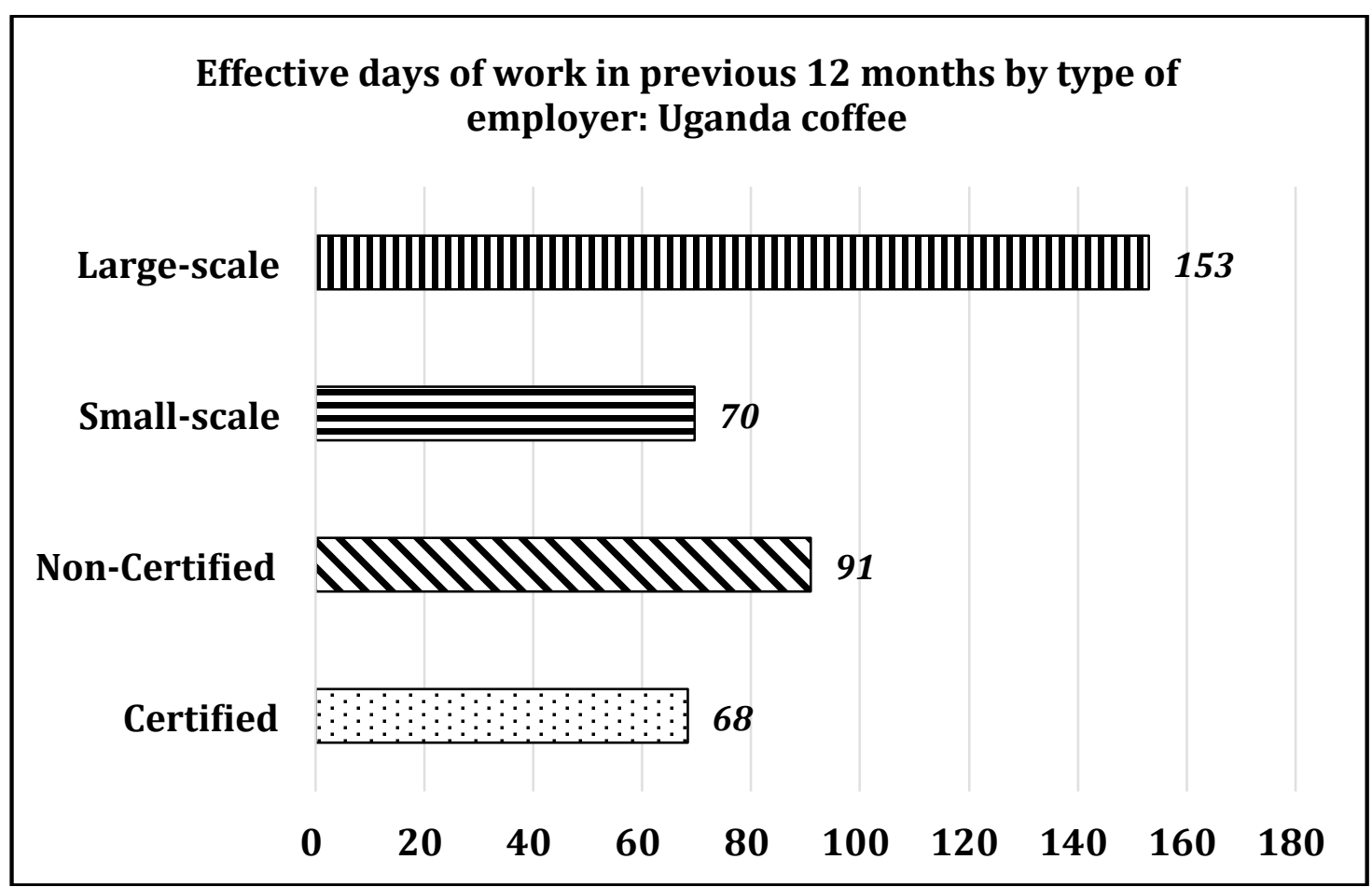

Notes: 1/ These figures are for comparable samples of manual coffee workers paid on a daily or monthly basis. 2/ The duration refers to individual jobs. 3/ 'certification' refers to Fairtrade certification.

Source: Cramer et al, 2014a. 
${ }^{1}$ For these claims, see:

http://www.fairtrade.net/about-fairtrade/what-is-fairtrade.html

We use Fairtrade to refer to the activities of Fairtrade International (FLO eV, FLO-CERT), as the main certifying body, Fairtrade producer networks, national

Fairtrade organizations and Fairtrade marketing organizations, while Fair Trade refers to the broader range of Fair Trade movement organizations, also called alternative trade organizations, which follow Fair Trade principles.

2 This paper is one output of the Fairtrade, Employment and Poverty Reduction in Ethiopia and Uganda research project (Cramer et al, 2014a), which undertook fieldwork in areas producing coffee and flowers (in Ethiopia) and coffee and tea (Uganda). The paper updates and adds to key findings from the main research report that focus on wages, while engaging with more recent literature on the effects of Fair Trade certification. The authors acknowledge the funding for the project from the Department for International Development (DfID), UK.

${ }^{3}$ Revised standards have only been published for a few countries and crops.

More importantly, they continue to ignore the widespread use of seasonal wage workers in SPOs, only specifying an arbitrary ceiling on the number of full-time employees 'small' producers may employ above which the standards apply (http://www.fairtrade.net/standards/our-standards/small-producerstandards.html).

${ }^{4}$ Rijsbergen et al 2016 select a control group matched to the intervention group using data on cooperative characteristics.

${ }^{5}$ Parvathi and Waibel (2016) note the problem of setting up a control group. They suggest that an alternative methodology is possible but this depends on strict assumptions regarding the random distribution of 'unobservables'. ${ }^{6}$ Detailed scoping in both Ethiopia and Uganda allowed researchers to identify sites where most if not all smallholder employers producing in a Fairtrade 'area' were actually members of and making some sales to a Fairtrade certified cooperative.

7 The PDA census confirmed the prevalence of wage work in all of the research sites.

${ }^{8}$ Labour supervisors and recruiters, government officials, cooperative managers and other employees, local processors and traders, company managers, auditors, some of the largest commodity exporters based in the capital city, and a wide range of other individuals were also interviewed.

${ }^{9}$ See World Bank (2007), Sender, Oya and Cramer (2005) and Oya (2013) on the neglect of rural wage employment in official statistics and policy debates and the implications for our understanding of rural poverty.

${ }_{10}$ Many studies make over-generalised assumptions about wages or take as accurate the wage rates reported by employers. Researchers on our team carefully calculated the daily equivalents of task wages. Information about varied time spent on each task, the diverse nature of tasks and overall pay was collected to convert wage receipts into daily rates. Qualitative research was also triangulated with the quantitative to produce consistent and reliable estimates. The various forms of payments were converted into comparable ('equivalent') daily rates across sites and crops. Moreover, for the areas where repeat surveys were conducted 1-2 years after the first surveys (coffee sites in Ethiopia and Uganda), nominal wages were converted to real wages using monthly food price 
indices. Qualitative research evidence was also used to triangulate information on local food prices and their changes over time.

11 We choose these two cases, because we keep one variable constant (commodity $=$ coffee) and because of the initial differences in descriptive analysis between Ethiopia and Uganda (Table 1). The results in tea (Uganda) and flowers (Ethiopia) are broadly similar in terms of the main factors and the negative association with FT certification. See full results in Appendix 3 of Cramer et al (2014a).

12 We also undertook Propensity Score Matching Analysis, focused on wage outcomes, in order to cross-check if the other comparisons are driven by a clear selection bias or not. The PSM results, reported in PROJECT and in a forthcoming paper (in progress), give a clear indication that the regression results shown in this paper are not biased. Due to space constraints we leave the PSM model and its detailed results to a separate paper.

13 'Small-scale' is a particularly fuzzy category. In this paper it is heuristically defined to include research sites described by most observers as smallholder areas. We also define small-scale employers to include all farmers who hire less than 10 workers at the peak of the harvest.

${ }^{14}$ See Cramer et al (2014a, chart 3.8 and 3.9).

15 As shown in Figure 2, the difference is somewhat larger in the case of Ethiopian coffee.

${ }^{16}$ See more detailed evidence in Cramer et al (2014a, pp. 82-90).

17 In Kaffa zone, certified coffee cooperatives have also been unable to disburse Fairtrade premium funds (Mitiku et al, 2015).

${ }^{18}$ Employers near Jimma claimed that they very frequently varied the piece rate they offered, depending on: the number of ripe cherries available; the availability of migrant labour; backlogs in processing capacity; and the rates offered by other employers competing for migrant labour.

${ }^{19}$ For additional evidence on child wage labour and its adverse effects on educational attainment in Ethiopia see Woldehanna and Gebremedhin (2015). On child labour in rural Uganda, see Muhumuza (2012).

${ }^{20}$ While we targeted wage workers aged over 14 years, a large proportion of them said they had been working since the age of 10 or earlier. We heard that this work was mostly carried out by children not attending school and bringing in income for their family. Qualitative work particularly generated evidence of a large number of child workers.

\section{References}

Amsden, Alice (2001). The Rise of 'The Rest': challenges to the West from late industrializing economies. Oxford: OUP.

Anand, S., \& Segal, P. (2014). The global distribution of income (Working Paper No. 2014-01). International Development Institute: Kings College, London. 
Central Statistical Agency and The World Bank (2013). Ethiopia Rural Socioeconomic Survey (Survey Report). Addis Ababa. Retrieved from http://go.worldbank.org/WV3F430XU0

Chan, A. (2010). Corporate Accountability and the Potential for Workers' Representation in China. Retrieved from http://epress.lib.uts.edu.au/research/handle/10453/14397

Chiputwa, B., D.J. Spielman, M. Qaim (2015). Food standards, certification, and poverty among coffee farmers in Uganda. World Development 66, 400-412.

COSA. 2013. The COSA Measuring Sustainability Report: Coffee and Cocoa in 12 Countries. Philadelphia, PA: The Committee on Sustainability Assessment

Cramer, C., D. Johnston, C. Oya and J. Sender (2014a), Fairtrade, Employment and Poverty Reduction in Ethiopia and Uganda: Final Report, London: SOAS, University of London.

Cramer, C., D. Johnston, C. Oya and J. Sender (2014b), 'How to do (and how not to do) fieldwork on Fair Trade and rural poverty', Canadian Journal of Development Studies, Vol.35 (1), pp.170-185.

Cramer, C. D. Johnston, C. Oya, and J. Sender (2014c), 'Fairtrade Cooperatives in Ethiopia and Uganda: Uncensored', Review of African Political Economy, Vol.41 (S1), pp.S115-S127.

Dammert, A. C., \& Mohan, S. (2014), 'A Survey of the Economics of Fair Trade', IZA Discussion Paper No. 8167, Bonn: Institute for the Study of Labour (IZA).

Dragusanu, R. and N. Nunn (2014), 'The impacts of Fair Trade certification: Evidence from Coffee Producers in Costa Rica (preliminary and incomplete)', http://scholar.harvard.edu/files/rdragusanu/files/draft_august_2013.pdf 
Fairtrade International (2015), Monitoring the Scope and Benefits of Fairtrade, Sixth Edition 2014.

Fields, G. S. (2007). Modeling Labor Market Policy in Developing Countries: A Selective Review of the Literature and Needs for the Future. Working Papers, 103. Cornell University.

International Initiative for Impact Evaluation (3ie). (2010). Fair and square: better market share, more benefits through Fairtrade. New Delhi.

International Trade Centre. (2011). The Impacts of Private Standards on Producers In Developing Countries. (Literature Review Series on the Impacts of Private Standards; Part II). Geneva: International Trade Centre (ITC).

Minten, B., Dereje, M., Engeda, E., \& Tamru, S. (2015). Who benefits from the rapidly increasing Voluntary Sustainability Standards? Evidence from Fairtrade and Organic certified coffee in Ethiopia. Working Paper 71. Addis Ababa: International Food Policy Research Institute (IFPRI).

Mitiku, F., de Mey, Y., Nyssen, J., \& Maertens, M. (2015). Do Private Sustainability Standards Contribute to Poverty Alleviation? A Comparison of Different Coffee Certification Schemes in Ethiopia. Bioeconomics Working Paper Series: WP 2015/03.

McCulloch, N., L.A. Winters, and X. Cirera (2001), Trade Liberalization and Poverty: A Handbook, London: UK Department for International Development and Centre for Economic Policy Research.

Wondwossen Mezlekia (2012). 'Ethiopia's coffee export nose-dives as government control backfires', Poorfarmer Coffee Politics Blog. Retrieved from 
http://poorfarmer.blogspot.fr/2012/07/ethiopias-coffee-export-nose-divesas.html

Muhumuza, T. (2012). Market Access and Child Labour: Survey Evidence from Rural Uganda (Discussion Paper No. 1251). Berlin: German Institute for Economic Research.

Nelson, V., \& B. Pound. (2009). The Last Ten Years: A Comprehensive Review of the Literature on the Impact of Fairtrade. Fairtrade Foundation.

Neuman, W. (2011). A Question of Fairness. New York Times, November 23rd, http://www.nytimes.com/2011/11/24/business/as-fair-trade-movementgrows-a-dispute-over-its-direction.html?_r=0 [Accessed on 22 July 2015]

Oya, C. (2013) 'Rural wage employment in Africa: methodological issues and emerging evidence.' Review of African Political Economy, 40 (136). pp. 251-273.

Oya, C. \& Pontara, N., eds. (2015). Rural Wage Employment in Developing Countries. Theory, Evidence and Policy. London: Routledge. (Routledge ISS Studies in Rural Livelihoods).

Parvathi, P. and H. Waibel (2016), 'Organic Agriculture and Fair Trade: A Happy Marriage? A Case Study of Certified Smallholder Black Pepper Farmers in India', World Development, 77, pp.206-220.

Rijsbergen, B. van, W. Elbers, R. Ruben, S. Njuguna (2016), 'The Ambivalent Impact of Coffee Certification on Farmers' Welfare: A Matched Panel Approach for Cooperatives in Central Kenya', World Development, 77, pp.277-292.

Ruben, R. (2013). Critical review of some recently published Fair Trade Impact Studies: Deficient study design and little robust evidence. Radboud University Nijmegen. 
Ruben, R. \& R. Fort (2012). 'The Impact of Fair Trade Certification for Coffee Farmers in Peru.' World Development 40(3): 570-82.

Ruben, R., \& Hoebink, P. (Eds.). (2015). Coffee certification in East Africa: impact on farms, families and cooperatives. Wageningen: Wageningen Academic Publishers.

Sender, J., Cramer, C., \& Oya, C. (2005). Unequal Prospects: Disparities in the Quantity and Quality of Labour Supply in sub-Saharan Africa. World Bank Social Protection Discussion Paper Series; No.0525

Smith, L. C., \& Haddad, L. (2015). 'Reducing Child Undernutrition: Past Drivers and Priorities for the Post-MDG Era', World Development, 68, 180-204.

Snilstveit, B., S. Oliver and M. Vojtokova (2012), 'Narrative approaches to systematic review and synthesis of evidence for international development policy and practice', Journal of Development Effectiveness, 4 (3), pp.409-29.

Taylor, M. (2011). 'Race you to the Bottom ... and Back Again? The Uneven Development of Labour Codes of Conduct', New Political Economy, 16(4), 445462.

Terstappen, Vincent, Lori Hanson, and Darrell McLaughlin. 2013. 'Gender, Health, Labor, and Inequities: A Review of the Fair and Alternative Trade Literature.' Agriculture and Human Values 30 (1): 21-39.

Thirlwall, A. P. (2011). 'Balance of Payments Constrained Growth Models : History and Overview', PSL (Paolo Sylos Labini) Quarterly Review, 64(259): 307351. 
Trauger, A. (2014). Is Bigger Better? The Small Farm Imaginary and Fair Trade Banana Production in the Dominican Republic. Annals of the Association of American Geographers, 104(5), 1082-1100.

Valkila, J. and A. Nygren (2009), 'Impacts of Fair Trade certification on coffee farmers, cooperatives, and laborers in Nicaragua', Agricultural Human Values, published online 22 May 2009.

Winters, L. A. (2002). Trade liberalisation and poverty: what are the links?. World Economy, 25, 1339-1367.

Woldehanna, T. and A. Gebremedhin (2015). Is Child Work Detrimental to the Educational Achievement of Children?: Results from Young Lives in Ethiopia (Working Paper No. 140). Oxford: Oxford Department of International Development (ODID), University of Oxford.

World Bank. (2007). World development report 2008: agriculture for development. Washington, D.C. : London: World Bank 